\title{
Structural Features of Polymer Nanocomposite LDPE-MWCNT in the Percolation Transition Region of Electrical Conductivity
}

\author{
M. A. Alieksandrov, A. I. Misiura, T. M. Pinchuk-Rugal,
} Yu. E. Grabovskii, A. P. Onanko, O. P. Dmytrenko, M. P. Kulish, E. L. Pavlenko, T. O. Busko, I. P. Pundyk, A. M. Gaponov, and A. I. Lesiuk

Taras Shevchenko National University of Kyiv,

64, Volodymyrska Str.,

UA-01033 Kyiv, Ukraine

The behaviour of electrical conductivity, $\sigma_{d c}$, in nanocomposites LDPEMWCNT, depending on the nanotubes' content, in the formation of the segregated filler morphology is considered. In this structure of nanocomposites, a low threshold value of percolation $\left(\varphi_{c}=0.00099\right.$ vol. fract.) is obtained. As shown, only at low concentrations of nanotubes, there is a correlation in the changes of the crystallinity degree and the indicated physical-mechanical characteristics revealed by the methods of determining the crystallinity degree and the dynamic elastic modulus, shear modulus, and Poisson's coefficients from the ultrasonic propagation velocities $(\sim 1 \mathrm{MHz})$. The orientational structure of the macromolecules adsorbed on the surface of the nanotubes appears at higher concentrations of MWCNT, when the crystallinity degree of the polymer matrix drops. The change in the polymer parameters that affects both the tunnelling of electrons in the region of interphase layers and, therefore, the change in electrical conductivity can be achieved by modifying the polymer matrix with $\pi$ conjugated materials, including dyes.

Розглянуто поведінку електропровідности $\sigma_{d c}$ у нанокомпозитах ПЕНГБВНТ залежно від вмісту нанотрубок, при формуванні сегрегованої морфології наповнювача. За такої структури нанокомпозитів одержано низьке значення порогу перколяції $\varphi_{c}=0,00099$ об. част. Методами визначення ступеня кристалічности, а також динамічних модулів пружности, зсуву, Пуассонового коефіцієнта за швидкостями поширення ультразвуку ( 1 МГц) показано, що лише за малих концентрацій нанотрубок має місце кореляція в змінах ступеня кристалічности та вказаних фізико-механічних характеристик. За більших концентрацій БВНТ, коли ступінь кристалічности полімерної матриці спадає, вини- 
кає орієнтаційна структура макромолекул, адсорбованих на поверхні нанотрубок. Зміну параметрів полімеру, яка впливає на тунельний перехід електронів в області міжфазних шарів, а отже, й на зміну електропровідности, може бути досягнуто шляхом модифікування полімерної матриці $\pi$-спряженими матеріялами, в тому числі барвниками.

Рассмотрено поведение электропроводности $\sigma_{d c}$ в нанокомпозитах ПЭНПМУНТ в зависимости от содержания нанотрубок при формировании сегрегированной морфологии наполнителя. При такой структуре нанокомпозитов получено низкое значение порога перколяции $\varphi_{c}=0,00099$ об. долей. Методами определения степени кристалличности, а также динамических модулей упругости, сдвига, коэффициента Пуассона по скоростям распространения ультразвука ( 1 МГц) показано, что только при малых концентрациях нанотрубок имеет место корреляция в изменениях степени кристалличности и указанных физико-механических характеристик. При больших концентрациях МУНТ, когда степень кристалличности полимерной матрицы спадает, возникает ориентационная структура макромолекул, адсорбированных на поверхности нанотрубок. Изменение параметров полимера, которое влияет на туннельный переход электронов в области межфазных слоёв, а значит, и на изменение электропроводности, может быть достигнуто путём модифицирования полимерной матрицы $\pi$-сопряжёнными материалами, в том числе красителями.

Key words: low-density polyethylene (LDPE), multi-walled carbon nanotubes (MWCNT), electrical conductivity, degree of crystallinity, dynamic modules, dyes.

Ключові слова: поліетилен низької густини (ПЕНГ), багатостінні вуглецеві нанотрубки (БВНТ), електропровідність, ступінь кристалічности, динамічні модулі, барвники.

Ключевые слова: полиэтилен низкой плотности (ПЭНП), многостенные углеродные нанотрубки (МУНТ), электропроводность, степень кристалличности, динамические модули, красители.

(Received 15 July, 2019)

\section{INTRODUCTION}

The use of polymers can be greatly expanded as a result of increasing their electrical conductivity, physical and mechanical properties $[1,2]$. Today, such an increase is being realized at the expense of the growth of internal and external conductivity $[3,4]$. The direction of creation of external conductivity due to the synthesis of polymeric composites of various natures is especially widespread [58]. Polymer nanocomposites with carbon nanotube as fillers are especially important. Their application is due to the peculiarities of 
the structure, geometry and unique electrical, thermal conductive (transport), mechanical, optical, emission, sorption and other properties [9-16]. In the case of polymer nanocomposites filled with nanotubes, as a result of the high aspect ratio of $l / D \sim 1000$, it is possible to expect an extremely low percolation threshold value, which essentially separates these nanocomposites among others [1723]. At the same time, due to the high values of the specific surface, the excipients considered are prone to aggregation with the formation of bundles as well as promote adsorption on their surface of polymer macromolecules. The deposited polymeric layers lead to a significant increase in the contact resistance between the adjacent nanotubes and, consequently, to the slow growth of electrical conductivity in the area of concentrations greater than the percolation threshold. The change in contact resistance can be achieved due to the influence on the structure of this layer, including due to the modification of the polymer matrix. The modification of the polymeric base by $\pi$-conjugated systems is interest. At the same time, the influence of the polymer matrix structure, its modification with various additives is insufficiently studied [24, 25].

The purpose of this work is to study the percolation behaviour of electrical conductivity in the LDPE-MWCNT system, influence the threshold of percolation of the segregated distribution of nanotubes, establish the role of the degree of crystallinity and orientation of the structure of macromolecules immobilized on the surface of the filler, in the concentration change of the and the dynamic elastic modulus, shear modulus, and Poisson's coefficient in the percolation region transition, as well as modification of the polymeric composite with the DBSQ squaraine dye.

\section{EXPERIMENTAL}

Composites of low-density polyethylene with multi-walled carbon nanotubes (MWCNT) synthesized by the method of low-temperature catalytic conversion were obtained by hot compression method. To obtain the polyethylene nanocomposites with MWCNT (PEMWCNT), high-pressure low-density polyethylene powder was thoroughly mixed with an appropriate number of MWCNT. Preparation temperature was $125-130^{\circ} \mathrm{C}$. The obtained LDPE-MWCNT composites were designed as discs with a diameter of $30 \mathrm{~mm}$. The concentrations of nanotubes in the polymer matrix were $0-0.030$ vol. fract.

The conductivity was determined at a constant current due to a thermometer E6-13A at room temperature. The study of the structure of LDPE-MWCNT nanocomposites was performed using an $\mathrm{x}$ ray diffractometer $\mathrm{DRON}-3 \mathrm{M}$ with monochromatic $\mathrm{Cu}_{K \alpha 1,2} \quad(\lambda=$ $=0.154178 \mathrm{~nm}$ ) radiation. For the investigation of mechanical prop- 
erties of nanocomposites LDPE-MWCNT, an ultrasonic KERN-4 computerized velocity meter was used. The dynamic elastic Young's modulus was determined by the formula:

$$
E^{\prime}=\rho V_{l}^{2},
$$

where $\rho$ is the sample density, $V_{l}$ is the velocity of quasilongitudinal ultrasonic elastic waves. The dynamic shear modulus was obtained by the formula:

$$
E^{\prime}=\rho V_{t r}^{2},
$$

where $V_{t r}$ is the velocity of quasi-transverse ultrasonic elastic waves. The Poisson's coefficient was calculated from the equation:

$$
v^{\prime}=\frac{1}{2} \frac{V_{l}^{2}}{V_{t r}^{2}}
$$

\section{RESULTS AND DISCUSSION}

The low value of the percolation threshold $\varphi_{c}$ can be achieved in the case of the formation of a segregated nanocomposite structure at using the MWCNT in the carbon-based polymer of polyethylene. Such a structure involves the formation of a continuous lead cluster by placing the filler in the spaces between the blocks of the polymer matrix [18].

Figure 1 shows the distribution of nanotubes in polyethylene with the increasing of filler concentration.

It can be seen that at low concentrations ( 0.001 vol. fract.) nanotubes are localized on the boundaries of the blocks of the polymer matrix, but they do not form a continuous conductivity cluster. The MWCNT localization becomes more pronounced and the cluster arises at the 0.002 vol. fract. concentration. With the subsequent increasing of MWCNT from 0.005 to 0.030 vol. fract., the segregated distribution disappears, and there is the aggregation of nanotubes, which densely fill the polymer volume.

Figure 2 shows the scaling behaviour of electrical conductivity in LDPE-MWCNT nanocomposites.

The fitting of experimental data was carried out with the scaling equation:

$$
\sigma=\sigma_{0}\left(\varphi-\varphi_{c}\right)^{t}
$$

where $\sigma_{0}$ is the conductivity of the dispersed filler in the composite, 

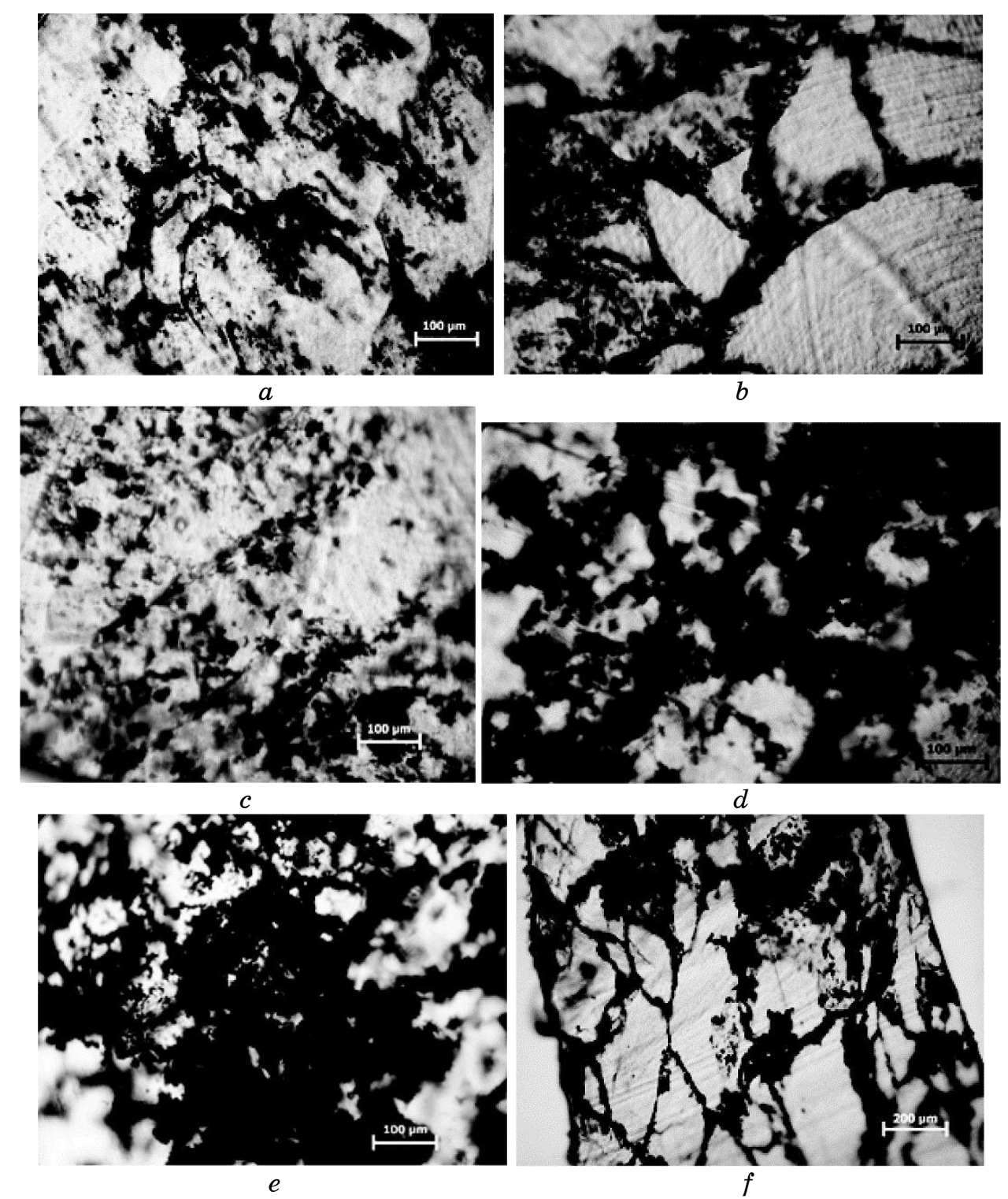

Fig. 1. Optical microscopy images of LDPE-MWCNT nanocomposites with $0.001(a), 0.002(b), 0.005(c), 0.007(d), 0.015(e), 0.030(f)$ vol. fract. MWCNT.

$\varphi$-the content of filler in the volume fractions, $\varphi_{c}$ - the percolation threshold, $t$-critical index.

The values of the parameters of Eq. (4) are given in Table. A very low value of the percolation threshold $\varphi_{c}=0.00099$ vol. fract. 


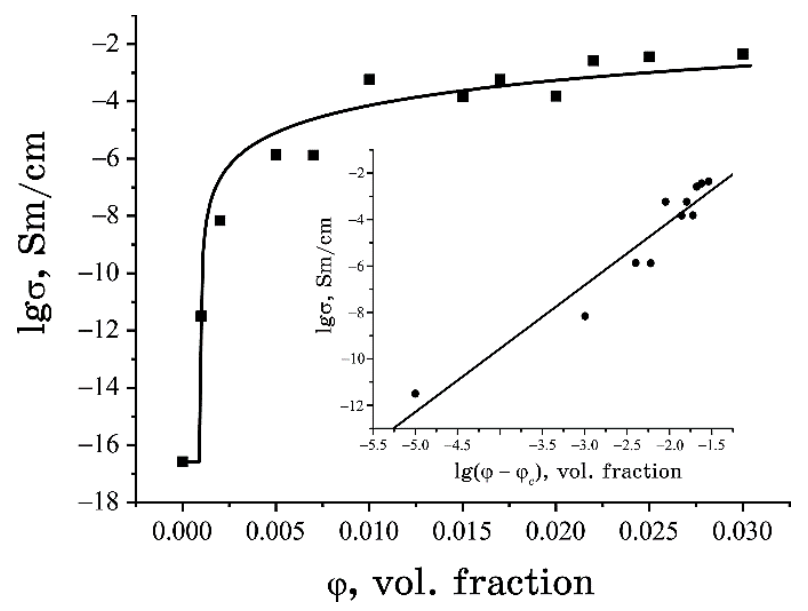

Fig. 2. Percolation curve of electrical conductivity of LDPE-MWCNT nanocomposites. (The insert shows the logarithmic dependence $\sigma \propto \varphi-\varphi_{c}$.)

TABLE. The value of scaling equation parameters of the electrical conductivity for LDPE-MWCNT nanocomposite.

\begin{tabular}{ccc|c}
\hline Nanocomposite & $\sigma_{0}, \mathrm{Sm} / \mathrm{cm}$ & $\varphi_{c}$, vol. fract. & $t$ \\
\hline LDPE-MWCNT & 23.9 & 0.00099 & 2.7 \\
\hline
\end{tabular}

occurs as a result of the segregated structure of the nanotube distribution. The last agrees with the results of similar nanocomposites formation. At the same time, the critical index $t=2.7$ remains close to the theoretical value obtained for the filler statistical distribution. The value $\sigma_{0}=23.9 \mathrm{Sm} / \mathrm{cm}$ appears to be much less than the electrical conductivity for the separated MWCNT, $\sigma_{\mathrm{NT}} \approx 10^{5}$ $\mathrm{Sm} / \mathrm{cm}$. Thus, the fabrication of nanocomposites with segregated distribution of nanotubes is an effective method for improving electrical conductivity at a small value for the percolation threshold. However, the problem of obtaining high values of electrical conductivity due to the strong influence of contact resistance remains unresolved.

As seen, after percolation threshold, the segregated structure is not stored due to the transition of nanotubes in the volume of the polymer matrix. As can be assumed in this case, the nanotubes' deposited polymer layer, which prevents the existence of osmotic contact between the particles of filler. The resistance of the indicated layer is significant $(\cong 3 \mu \mathrm{m})$, so, the increase in electrical conductivity, despite the increase in the content of nanotubes, is negligible [26]. Since, in this structural configuration, the electrical conductivity is mainly provided by tunnelling of electrons through the 
barrier created by the polymeric layer, it is important to modify these polymer layers in order to reduce the role of the considered potential barrier [27, 28]. Such a modification of the layer may be due to a change in its structure by the orientation of the placement of polymeric macrochains on nanotubes, which can be controlled by the functionalization of the filler [29]. In addition, it is possible to change the properties of the polymer matrix due to the introduction of different nature modifiers. Thus, the external modification is effective when the ion systems are applied to the polymer, which greatly affects the electrical conductivity of nanotube composites [30-36]. In the presence of modifiers in the polymer, a McLachlan model, which takes into account the conductivity of the polymer matrix [26, 28], is more suitable for describing the electrical conductivity. Perspective modifiers may appear to be conjugate systems with delocalized $\pi$-electrons, for example, dyes [37-45], graphene [46], fullerenes [47-50]. Thus, in the case of doping a PVA/PVP polymer mixture with a methylene blue dye, with increasing content of the modifier and temperature, the increase in conductivity at a constant current $\sigma_{d c}$ is observed. Doping nanocomposite with 0.0092 vol. fract. of MWCNT, that is beyond the boundary of the percolation region $\varphi>>\varphi_{c}$ with the squaraine DBSQ dye with concentrations of 0.0026 and 0.0156 vol. fract., leads to a slight drop in electrical conductivity of $\lg \sigma_{d c}$ from $-3.47 \mathrm{Sm} / \mathrm{cm}$ for the unmodified composite to $-\mathbf{4 . 2 5}$ and $-4.47 \mathrm{Sm} / \mathrm{cm}$ for the indicated dye concentrations, respectively. It is evident that, with increasing content of dye, the drop in electrical conductivity decreases. One of the reasons of such decrease in electrical conductivity may be competition in the deterioration of the conductivity of a continuous cluster due to the disorientating effect of the dye and its increase as a result of improved tunnelling of the charges in the contact layer between adjacent nanotubes.

The parameters of scaling dependence change little with the doping of LDPE-MWCNT nanocomposite by DBSQ dye (0.156 vol. fract.).

When forming the corresponding structure of the polymer matrix in the contact layer, one can expect the effect of the modifier on the electrical conductivity of nanocomposites. The appearance of the characteristics of the polymer structure around the filler and the effect on it of modifiers must be accompanied by a change in the physical and mechanical properties, including the dynamic elastic modulus, shear modulus [51-60]. An important part of the restructuring of the structure in the presence of filler and modifier is the change in the crystalline degree.

Figure 3 shows the x-ray diffraction pattern for LDPE-MWCNT nanocomposite with different content of nanotubes.

As seen, the polyethylene crystalline structure remains un- 

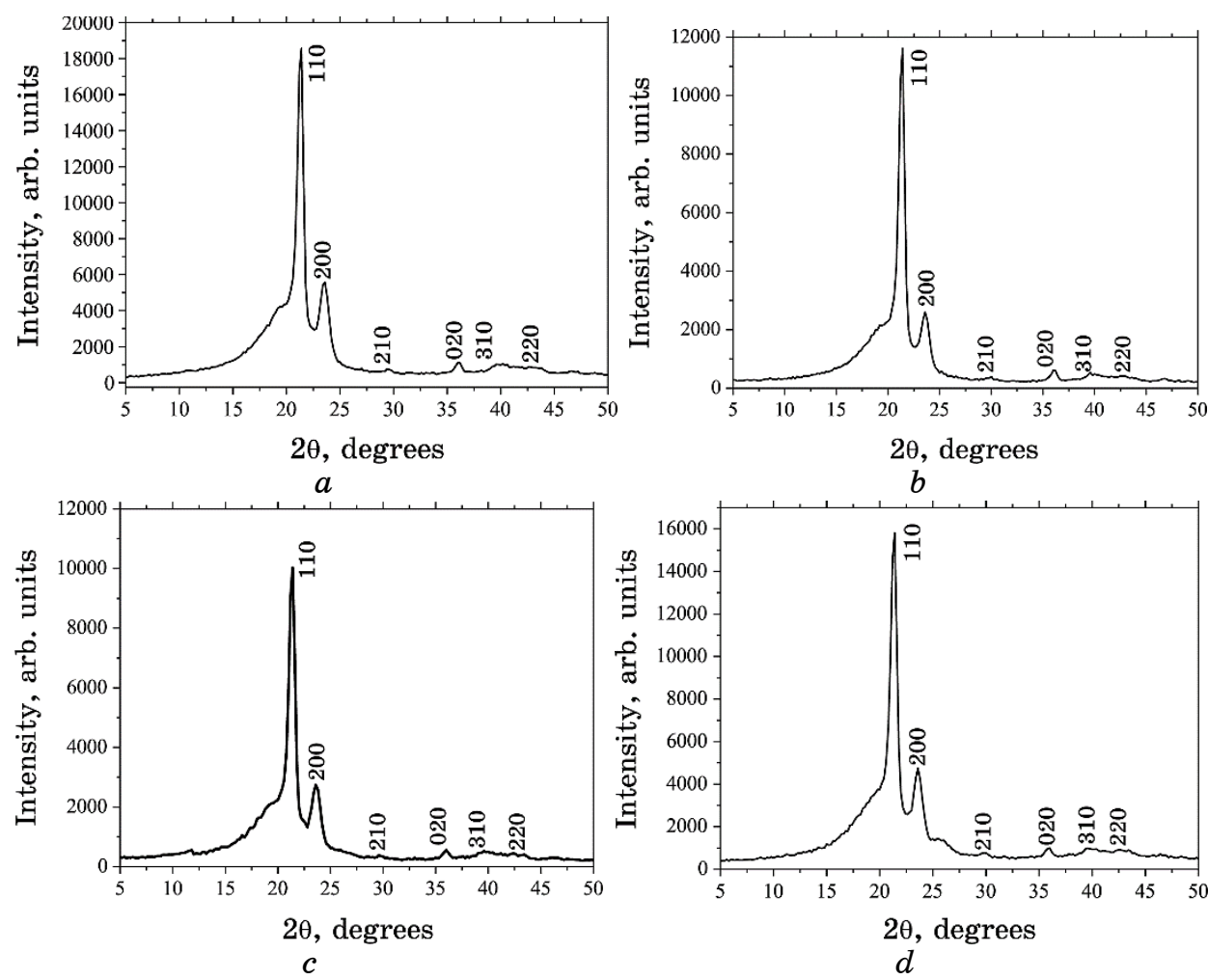

Fig. 3. X-ray diffraction patterns for LDPE-MWCNT nanocomposites with $0(a), 0.002(b), 0.01(c), 0.03(d)$ vol. fract. MWCNT $\left(\lambda_{\mathrm{CuK \alpha} \alpha, 2}=0.154178\right.$ $\mathrm{nm})$.

changed during doping with nanotubes. At the same time, a significant change in the crystallinity degree is observed with the change in the nanotubes content. The behaviour of the crystallinity degree together with the concentration dependence of the dynamic Young's modulus $E^{\prime}$, shear modulus $G^{\prime}$, and the Poisson's coefficient are shown in Fig. 4.

It can be seen that, with the increasing of MWCNT concentration, the crystallinity degree changes not monotonously, which also occurs in other nanocomposites [61-63]. Two maxima of crystallinity degree were observed at lower concentrations. There is one of them at 0.002 vol. fract. MWCNT and second one, smaller in size, at 0.01 vol. fract. MWCNT. The crystallinity degree decreases with the increasing $\varphi$ after the first maximum. The first maximum is due to the sufficient dispersion of nanotubes, which act as crystallization centres in polyethylene when interacting with polymer chains. With the nanotube formation harnesses during their aggre- 


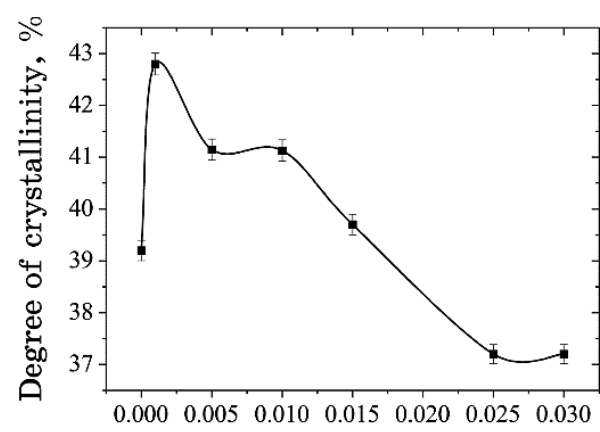

MWCNT content, vol. fraction

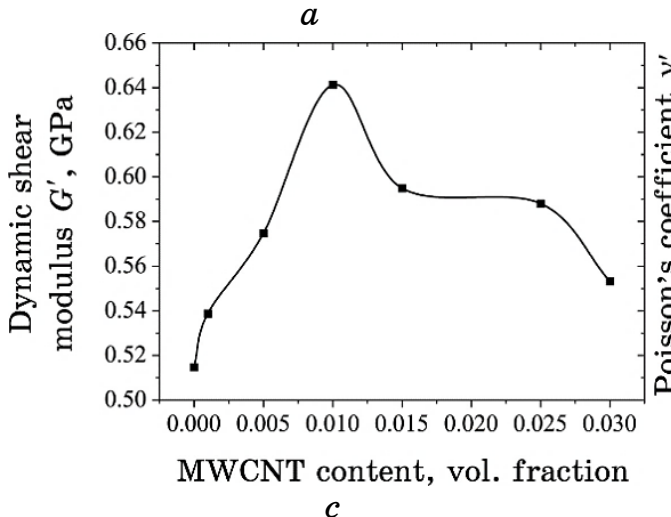

$c$

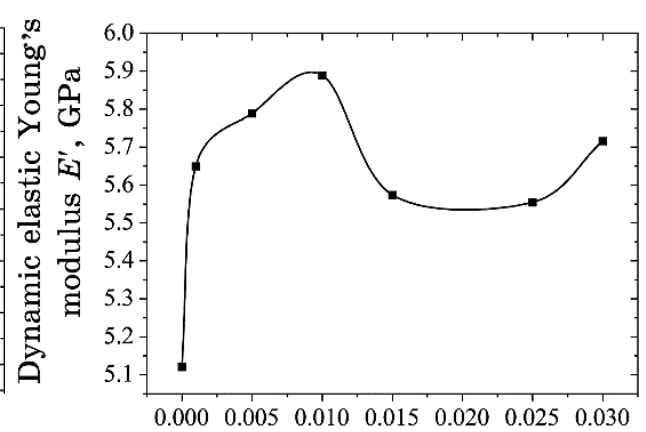

MWCNT content, vol. fraction $b$

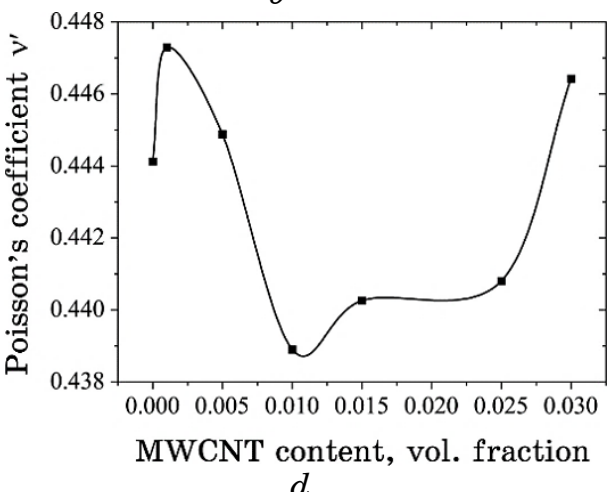

$d$

Fig. 4. Concentration dependence of the degree of crystallinity (a), dynamic elastic Young's modulus (b), dynamic shear modulus $(c)$, and the Poisson's coefficient $(d)$ for LDPE-MWCNT nanocomposites (frequency of 1 $\mathrm{MHz}$ for $E^{\prime}$ and $0.7 \mathrm{MHz}$ for $\left.G^{\prime}\right)$.

gation, the mechanism of crystallization involves the appearance of polymer layers between adjacent nanotubes, in which the crystallization process is amplified.

The behaviour of Young's dynamic elastic modulus $E^{\prime}$ with increasing concentration of nanotubes is also nonmonotonic, but it only correlates with a change in the degree of crystallinity in the region of smaller concentrations. This shows that, for the higher content of MWCNT, when the degree of crystallinity drops, the orientation towards the structurization of macromolecules adsorbed on nanotubes plays an important role. The role of these structured layers increases with MWCNT concentration increasing. It is seen that, in the region of the crystallinity degree growth, the dynamic module $E^{\prime}$ sharply increases, and in the future, its increased value remains with the tendency of a slight increase due to the formation of the oriented structure in the considered layers. The specified struc- 
ture to a lesser extent correlates with the displacement module $G^{\prime}$. As can be seen, with the fall of the degree of crystallinity, this module falls, but to a lesser extent than the crystallinity degree, indicating an important role in maintaining the increased value of $G^{\prime}$ in a wide concentration range. The role of these polymeric layers is especially noticeable when considering the concentration dependence of the Poisson coefficient $v^{\prime}$. The higher content of MWCNT the more sharp value growth is observed.

Thus, the doping of polyethylene with nanotubes results not only in the change in the degree of crystallinity, which plays an important role in increasing $E^{\prime}, G^{\prime}$ modules, the Poisson's coefficient $v^{\prime}$ for the lower content of MWCNT. The orientation of the macromolecules' structurization in polymer layers between adjacent nanotubes at higher concentrations of nanotubes plays important role.

\section{CONCLUSIONS}

By forming a segregated structure of MWCNT in LDPE polymer matrix, a percolation curve with a low percolation threshold $\varphi_{c}=$ $=0.00099$ vol. fract. were obtained. As the content of nanotubes increases, the segregated dispersion of the filler disappears and the distribution of MWCNT becomes more homogeneous. When modifying the nanocomposite of LDPE-MWCNT with DBSQ as a conjugate molecule in the region $\varphi>\varphi_{c}$, a slight drop in conductivity is observed.

The determination of the concentration dependences of the crystallinity degree and the dynamic elastic modulus, shear modulus, and Poisson's coefficient shows that the correlation between the degree of crystallinity and the mentioned mechanical characteristics takes place only for a small content of nanotubes. The higher MWCNT content, the degree of crystallinity drops, and the specified modules and the Poisson's coefficient retain their values due to the structural orientation of macromolecules adsorbed on the surface of nanotubes.

\section{REFERENCES}

1. B. I. Sazhin, Electrical Properties of Polymers (Leningrad: Khimiya: 1977) (in Russian).

2. D. F. O'Regan, M. Akay, and B. Meenan, Composites Science and Technology, 59: 419 (1999); https://doi.org/10.1016/S0266-3538(98)00089-X.

3. F. Garnier, Uspekhi Fizicheskikh Nauk, 157, No. 3: 513 (1989) (in Russian).

4. A. R. Blythe and D. Bloor, Electrical Properties of Polymers (Moscow: Fizmatlit: 2008) (Russian translation).

5. Ye. P. Mamunya, Journal of Macromolecular Science. Part B, 38, Nos. 5-6: 
615 (1999); DOI: 10.1080/00222349908248125.

6. Ye. Mamunya, M. Iurzhenko, E. Lebedev et al., Electroactive Polymer Materials (Kyiv: Alfa Reklama: 2013) (in Ukrainian).

7. G. V. Kozlov, Uspekhi Fizicheskikh Nauk, 185, No. 1: 35 (2015) (in Russian).

8. A. T. Ponomarenko, A. R. Tameev, and V. G. Shevchenko, Uspekhi Khimii, 87: 923 (2018).

9. A. V. Eletskii, Uspekhi Fizicheskikh Nauk, 167, No. 9: 945 (1997) (in Russian).

10. E. G. Rakov, Uspekhi Khimii, 70: 943 (2001).

11. A. V. Eletskii, Uspekhi Fizicheskikh Nauk, 172, No. 4: 401 (2002) (in Russian).

12. A. V. Eletskii, Uspekhi Fizicheskikh Nauk, 174, No. 11: 1191 (2004) (in Russian).

13. A. V. Eletskii, Uspekhi Fizicheskikh Nauk, 177, No. 3: 223 (2007) (in Russian).

14. A. V. Eletskii, Uspekhi Fizicheskikh Nauk, 179, No. 3: 225 (2009) (in Russian).

15. A. V. Eletskii, Uspekhi Fizicheskikh Nauk, 180, No. 9: 897 (2010) (in Russian).

16. A. V. Eletskii, Uspekhi Fizicheskikh Nauk, 185, No. 3: 225 (2015) (in Russian).

17. P. J. Harris, International Materials Reviews, 49, Iss. 1: 31 (2004); DOI: 10.1179/095066004225010505.

18. M. O. Lisunova, Y. P. Mamunya, N. I. Lebovka, and A. V. Melezhyk, European Polymer Journal, 43, No. 3: 949 (2007); doi:10.1016/j.eurpolymj.2006.12.015.

19. C. Min, X. Shen, Z. Shi, L. Chen, and Zh. Xu, Polymer-Plastics Technol. Eng., 49, Iss. 12: 1172 (2010); https://doi.org/10.1080/03602559.2010.496405.

20. Z. Spitalsky, D. Tasis, K. Papagelis, and C. Galiotis, Prog. Polymer Science, 35, Iss. 3: 357 (2010); https://doi.org/10.1016/j.progpolymsci.2009.09.003.

21. E. R. Badamshina, M. P. Gafurova, and Ya. I. Estrin, Uspekhi Khimii, 79: 1028 (2010) (in Russian).

22. G. Cavallaro, R. De Lisi, G. Lazzara, and S. Milioto, J. Therm. Anal. Calorimetry, 112: 383 (2013); https://doi.org/10.1007/s10973-012-2766-8.

23. L. Bardash, G. Boiteux, R. Grykien, I. Giowacki, M. Pastorczak, J. Ulanski, and A. M. Fainleib, Polymer Journal, 40, No. 4: 230 (2018); DOI: $10.15407 /$ polymerj.40.04.230.

24. A. L. Svistunov, L. A. Komar, G. Heinrich et al., Polymer Science, 50, No. 5: 903 (2008) (in Russian).

25. B. A. Komarov, E. A. Dzhavadyan, V. I. Irzhak et al., Polymer Science, 53, No. 6: 903 (2011) (in Russian).

26. D. S. McLachlan, Physica A, 157, Iss. 1: 188 (1989); https://doi.org/10.1016/0378-4371(89)90299-9.

27. D. S. McLachlan, C. Chiteme, W. D. Heiss, and J. Wu, Physica B, 338, Iss. 1-4: 261 (2003); https://doi.org/10.1016/j.physb.2003.08.003.

28. D. S. McLachlan, C. Chiteme, W. D. Heiss, and J. Wu, Physica B, 338, Iss. 1-4: 256 (2003); https://doi.org/10.1016/j.physb.2003.08.002.

29. D. S. McLachlan and G. Sauti, J. Nanomater., 3: 1 (2007); https://doi.org/10.1155/2007/30389.

30. E. A. Lysenkov, Yu. V. Yakovlev, and V. V. Klepko, Polymer Journal, 35: 259 (2013) (in Ukrainian).

31. E. A. Lysenkov and V. V. Klepko, Journal of Nano- and Electronic Physics, 5, No. 3: 03052 (2013) (in Ukrainian).

32. Z. O. Haholkina, E. V. Lobko, Yu. V. Yakovlev et al., Polymer Journal, 37, No. 2: 157 (2015) (in Ukrainian).

33. E. A. Lysenkov, V. V. Klepko, and Yu. V. Yakovlev, Journal of Nano- and Electronic Physics, 7, No. 1: 01031 (2015) (in Ukrainian).

34. E. A. Lysenkov, V. V. Klepko, and Yu. V. Yakovlev, Surface Engineering 
and Applied Elastochemistry, 52: 62 (2016) (in Russian).

35. E. A. Lysenkov, Z. O. Haholkina, E. V. Lobko, M. H. Tkalich, and V. V. Klepko, Mater. Sci., 53, No. 1: 14 (2017); https://doi.org/10.1007/s11003-017-0037-3.

36. E. V. Lobko, Z. O. Gagolkina, Yu. V. Yakovlev, E. A. Lysenkov, and V. V. Klepko, Nanosistemi, Nanomateriali, Nanotehnologii, 15, No. 2: 345 (2017) (in Ukrainian); https://doi.org/10.15407/nnn.15.02.0345.

37. S. Kivelson, Phys. Rev. B, 25, No. 5: 3798 (1982).

38. J. L. Brédas, R. R. Chance, and R. Silbey, Phys. Rev. B, 26, No. 10: 5843 (1982).

39. P. Kuivalainen, H. Stubb, H. Isotalo, P. Yli-Lahti, and C. Holmström, Phys. Rev. B, 31, No. 12: 7900 (1985).

40. A. V. Tkachev, D. N. Kiselev, V. A. Tverskoi et al., Polymer Science, 36, No. 8: 1326 (1994) (in Russian).

41. H. M. Zidan, A. Tawansi, and M. Abu-Elnader, Physica B, 339: 78 (2003).

42. H. M. Zidan, J. Polymer Science, 41: 112 (2003).

43. H. M. Zidan and M. Abu-Elnader, Physica B, 355: 308 (2005).

44. H. M. Zidan, A. El-Khodary, I. A. El-Sayed, and H. I. El-Bohy, J. Applied Polymer Sci., 117: 1416 (2010); https://doi.org/10.1002/app.31939.

45. H. M. Zidan, N. A. El-Ghamaz, A. M. Abdelghany, and A. L. Waly, Int. J. Electrochem. Sci., 11: 9041 (2016); https://doi.org/10.1016/j.saa.2018.03.057.

46. A. D. Kachkovsky, E. L. Pavlenko, E. V. Sheludko et al., Functional Materials, 26, No. 1: 1 (2017).

47. G. P. Karpacheva, Polymer Science, 42, No. 11: 1974 (2000) (in Russian).

48. M. G. Krakovyak, E. V. Anufrieva, T. D. Anan'eva et al., Polymer Science, 48, No. 6: 926 (2006) (in Russian).

49. E. R. Badamshina and M. P. Gafurova, Polymer Science, 49, No. 7: 1306 (2007) (in Russian).

50. E. R. Badamshina and M. P. Gafurova, Polymer Science, 5, No. 8: 1572 (2008) (in Russian).

51. K. Joseph, S. Thomas, and C. Pavithran, J. Reinforced Plast. Compos., 12: 139 (1993).

52. D. Blond, V. Barron, M. Ruether et al., Adv. Funct. Matter., 16: 1608 (2006).

53. C. S. Reddy and C. K. Das, Polymers \& Polymer Composites, 14, No. 3: 281 (2006).

54. A. Mierczynska, M. Mayne-L'Hermite, G. Boiteux, and J. K. Jeszka, J. of Applied Polymer Sci., 105: 158 (2007); DOI 10.1002/app.26044.

55. C. N. Della and D. Shu, Solid State Phenomena, 146: 45 (2008).

56. R. N. Brandalise, M. Zeni, J. D. N. Martins, M. M. C. Forte, Polymer Bulletin, 62: 33 (2009); https://doi.org/10.1007/s00289-008-0989-4.

57. K. Sewda and S. N. Maiti, Polymer Bulletin, 70: 2657 (2013).

58. M. Sabet and H. Soleimanti, IOP Conf. Series Matter. Eng., 64: 012001 (2014).

59. A. I. Misiura, Y. P. Mamunya, V. L. Demchenko et al., Polymer Journal, 39, No. 3: 154 (2017) (in Ukrainian).

60. L. Li, L. Zhong, K. Zhang, J. Gao, and M. Xu, Materials, 11, No. 10: 1922 (2018); https://doi.org/10.3390/ma11101922.

61. E. R. Badamshina, Ya. I. Estrin, and A. A. Grischuk, Polymer Science, 54, No 4: 568 (2012) (in Russian).

62. T. M. Pinchuk-Rugal, O. S. Nychyporenko, O. P. Dmytrenko et al., Problems of Atomic Science and Technology, 5: 173 (2013).

63. O. S. Nychyporenko, O. P. Dmytrenko, T. M. Pinchuk-Rugal et al., Problems of Atomic Science and Technology, 2: 99 (2016). 